\title{
Geoenvironmental study of alluvial aquifer in Upper Gangetic plain, a case study of J P Nagar, Uttar Pradesh, India
}

\author{
Vikas Kamal $^{1}$, Saumitra Mukherjee ${ }^{1}$, Deepika Srivastava ${ }^{1}$, Naba Hazarika $^{1}$ and \\ Neha Singh ${ }^{1}$ \\ ${ }^{\text {I}}$ School of Environmental Sciences, Jawaharlal Nehru University, New Delhi-110067, India)
}

\begin{abstract}
Water quality is very important if we take into account the human paradigm in the environment. Groundwater constitutes the $30.1 \%$ of the freshwater reserves on earth. Gangetic plains in India have the highest density of groundwater extraction structures. 50 samples were taken in total from J P Nagar district of which there were 3 river water samples and 6 were groundwater samples falling just outside the district boundary. Using statistical and GIS analysis various indices were calculated. WQI or water quality index revealed a zone of high pollution across the district. Hydrochemical plots like Piper, Durov and Chaddha diagram brought out the information about the water type in the area. Mineralogy of the study area shows the dominance of feldspar minerals. Land cover change between 1998 and 2013 has been deciphered from supervised classification of Landsat data of USGS.
\end{abstract}

Keywords: Ganga plain, J P Nagar, groundwater, interfluve, hydrochemical facies, stability diagram

\section{Introduction}

Groundwater reserves of the Ganga plain are so huge that even the GRACE (Gravity Recovery and Climate Experiment) satellite could detect it from hundreds of kilometres away. Though, its use for Indian scenario is not endorsed by many [1]. People in India highly depend upon this reserve because canal system is not so well developed to cater to the huge demand for irrigation, industries and agriculture. This has led to its exploitation at an unprecedented rate than ever before. Over exploitation is readily visible on the ground with the presence of a handpump or tubewell in almost every household of the area. Irrigation puts the groundwater in a cycle that involves interaction with chemicals, pesticides and fertilizers. Thus excessive use of groundwater resource has detrimentally affected its quality and quantity [2].

The main factors that control the chemical character of groundwater are the climate and vegetation cover, the mineral composition and physical properties of rock and soil through which the water circulates and the relief of the land surface [3]. Further, geochemical processes occurring within the groundwater are responsible for seasonal and spatial variations in groundwater chemistry [4]. The present study was performed to cover all the major aspects governing the groundwater chemistry of the region through hydrochemical plots, spatial profile of the region and water quality index. Large number of the samples, collected over the region offer clues to geochemical processing in a comprehensive manner. The study area is a small part of the Ganga plain and includes both newer and older alluvium. In the recent past this area has gone through rapid industrialization and population explosion though it is an agricultural area [5]. The ephemeral streams in the area are used for discharging industrial waste that has contaminated the aquifer in this region. In this background the present study was undertaken to comprehensively study the groundwater chemistry of the area.

1.1 Study Area

Jyotiba Phule Nagar (J P Nagar) district with an area of 2,249 sq. kms forms a part of the western region of Uttar Pradesh state of India in Northern Ganga plain. Jyotiba PhuleNagar lies between $28^{\circ} 20^{\prime}$ north latitudes and $78^{\circ} 40^{\prime}$ east longitude. Bijnor district bounds it from northern side while Moradabad bounds it from eastern side. The river Ganga forms its natural western boundary and separates it from Bulandshahr, Ghaziabad and Meerut district. The district is drained by the Ganga and its tributaries namely Sot, Ban, Gangan and Tikta. It lies in the interfluve area between the river Ganga and Ramganga. The area is less diversified in terms of agriculture as compared to the whole state. Sugarcane, oilseeds and other commercial crop like peppermint are cultivated more in this district. 99 per cent irrigation is done through tubewell which are privately owned. Industrially the region is backward with only eight factories registered by 2005-2006. Tubewell and handpumps are the main source of drinking water in this district [6]. 

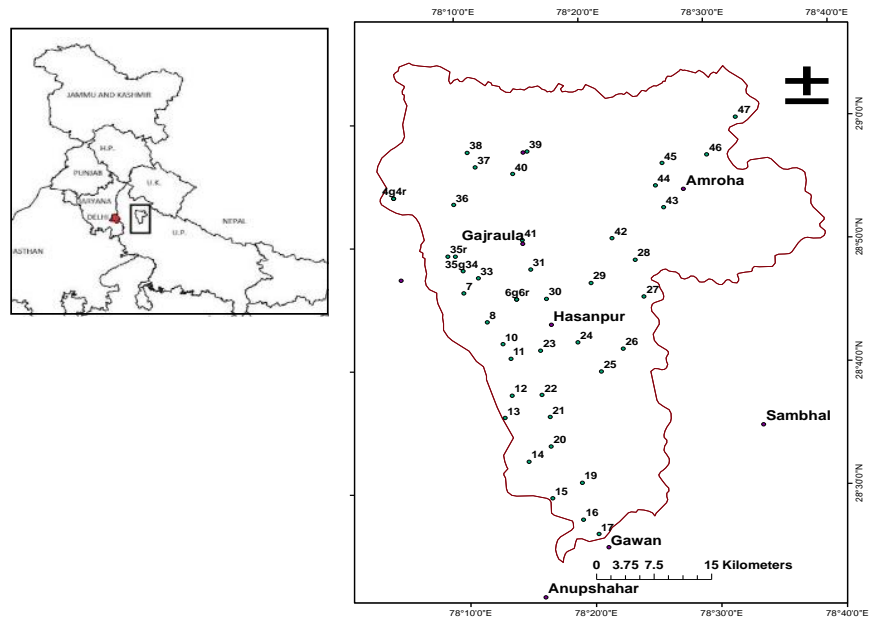

Figure 1: Map of District J P Nagar with its location shown in inset and sampling points

Lithology is alluvium dominated, reported to be $1000 \mathrm{~m}$ thick by oil and natural gas corporation (ONGC). It comprises of clay, silt and various grades of sand. Upto 390m, one obtains a uniform sedimentation after which a change is observed. The upper $180 \mathrm{~m}$ aquifer group is exploited heavily. As reported in 2006 by CGWB (Central Ground Water Board), the water level shows a declining trend in this area.

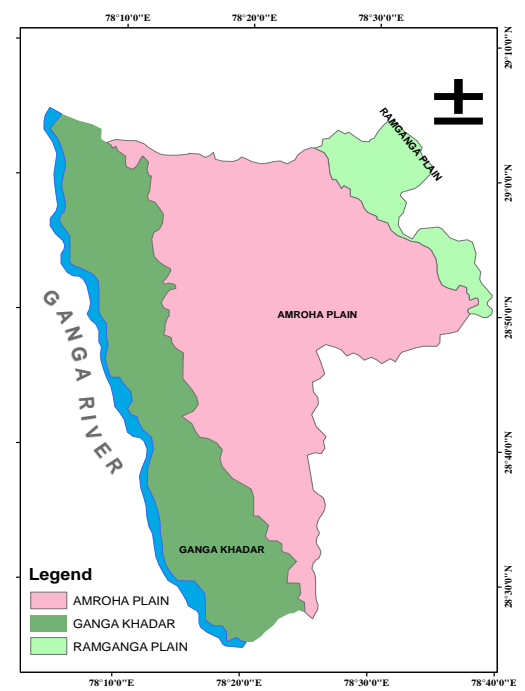

Figure 2: Submicro regions in the study area (adapted from Regional divisions of India- a cartographic analysis series 1, Uttar Pradesh, Vol. 22)[7]

On the basis of geology, soils, topography, climate and natural vegetation, the district has three submicro regions:
a) Ganga Khadar.
b) Ramganga Plain
c) Amroha Plain.

The Ganga Khadar or lowland region lies in $12 \mathrm{~km}$ width alongside bhur division or sandy tract region on the Ganga river bank. The major part of Ganga Khadar used to be water logged which is now protected by high rise road running alongside the western margin. Being in proximity of the Himalayas and Tarai swamps, the climate of the district is very hot in summers and severe cold in winters. The district has no dense vegetation in any part. JhauandDhak jungle used to exist in Ganga Khadar region in early 60's. At present the area is highly cultivated with capital crops [7]. Geologically the region belongs to Alluvium, Dun gravels (recent), while the main soil suborders associations are Ochrepts-Aquepts-Ustalfs, Psamments-Fluvents and Psamments-FluventsAquents. The Ramganga canal system covers irrigation requirements in this region. Ganga Khadar is spread over along the Ganga in north-south direction in the Hasanpur tehsil and is liable to floods. The slope is very gentle and parallel to flow direction of the river Ganga. There are number of depressions, small rivulets and dead arms of the river. The $200 \mathrm{~m}$ contour marks roughly the eastern limit of the region. There are numerous 
small streams originating from the local depressions and after flowing some distance parallel to the Ganga join it. They are all ephemeral in nature [7].

Ramganga plain lies in the north-eastern part of the district, is characterized by tarai belt. Main stream is Gangan which is also a non-perennial tributary of the Ramganga. Kanth is the major urban centre here. Slope is steep. Tumaria canal system irrigates the area [7].

Amroha plain is flat plain with little physiographic variation. Slope is gentle towards south. Sot and Ban are the major non-perennial streams. Sot River joins the Ganga beyond this region whereas Ban is the tributary of Ramganga. Plantation belt around Amroha town is quite extensive. Ramganga canal system serves irrigational requirement of this belt. In the study area, Amroha, Naugawan Sadat, Joya, Dhanaura, Bachhraon, Hasanpur and Ujhari are the main urban centres [7].

\section{Materials And Methods}

The sampling of groundwater was carried out in the month of March 2013, from locations selected randomly so as to cover overall study area. Polypropylene bottles of $250 \mathrm{ml}$ and $125 \mathrm{ml}$ were used to collect groundwater samples. Hand pumps and tube wells dug by the government and local people were used to sample the water. Water from first 20-25 strokes was discarded and then sampled to avoid contamination from iron pipe of hand pump. pH, electrical conductivity (EC), temperature and total dissolved solid (TDS) were estimated in the field. Sample in $125 \mathrm{ml}$ bottle was acidified with 1-2 drops of conc. nitric acid in the field and filtered using $0.45 \mu$ filter paper (Millipore)for further analysis of cations and heavy metals. Non-acidified samples were used for analysis of anions. Later the samples were kept in refrigerator at $4^{\circ} \mathrm{C}$ to prevent organic growth in the sample. All the analysis was done within 15 days after bringing the samples to laboratory.

$\mathrm{pH}, \mathrm{EC}$ and TDS were observed by portable meters of HANNA. These meters were calibrated first using buffer solutions of $\mathrm{pH}$ 4.0, 7.0 and 9.2 (Fisher Scientific) and $\mathrm{KCl}$ and $\mathrm{NaCl}$ solution of known $\mathrm{EC}$ and TDS respectively. Bicarbonate was analysed through volumetric method. Sulphate was determined by turbidimetric method. Fluoride was quantified by ion selective electrode method. Chloride, phosphate and silica were estimated using method described by Dialtoff and Rengel 2007, using Perkin Elmer UV-VIS spectrophotometer. Na, K andCa were estimated using flame photometer [8]. Mercury, Selenium, Arsenic, Cyanide and Antimony were determined by standard methods of APHA and heavy metals like $\mathrm{Fe}, \mathrm{Pb}, \mathrm{Mn}, \mathrm{Cu}$, $\mathrm{Cd}$, Co were determined by using AAS (Atomic Absorption Spectrophotometer) of Thermo Scientific Co. Ltd.

GSI toposheet of 1:50000 scale was used to decide the route and location before sampling. Garmin GPS was carried in the field to mark the location and path. At each point latitude and longitude were noted down and the temperature, $\mathrm{pH}$ and TDS reading were taken by dipping the probe of electronic thermometer into the sampled water. After generating all the required data, data analysis was carried out with the help of software like AqQa and ArcGIS 10 spatial analyst module. Microsoft Excel was used to generate various statistical graphs and plots. Landsat data from USGS Earth explorer was used to generate land cover with the help of ERDAS IMAGINE 9.3 software.

\subsection{General Chemistry}

\section{Results and Discussion}

The parameters tested in the water samples collected are shown in the Table 2 with their maximum, minimum, average and standard deviation values. Conductivity, bicarbonate, TDS, silica, chloride, calcium and ammonium show a high standard deviation values because of influence of natural and anthropogenic factors over space and time. High average values of conductivity, TDS, silica, bicarbonate, chloride, sulphate, calcium, magnesium and ammonium show that carbonate chemistry is playing a major role in the groundwater chemistry. High ammonium values are due to agriculture activities practiced intensively in the region [9].

Mean $\mathrm{pH}$ value of 8.6 represents alkaline nature of the groundwater in the study area (Drever 1988). EC value varied from 240 to $1515 \mu \mathrm{S} / \mathrm{cm}$ with an average value of $650 \mu \mathrm{S} / \mathrm{cm}$. Higher EC values are found to be associated with the Amroha plain area and deeper tubewells. EC and TDS values were measured by portable meter in the field itself which correlate well (Table 1). EC also correlates with bicarbonate, chloride, calcium and ammonium values to a good extent. TDS values were measured in field and values found showed that as per Davis and Deweist (1966) [10] classification only two water samples of Dehri and Rajoha fall under permissible limit and rest fall under desirable criteria. The water sampled here was unusually yellowish red in colour as visible in the photograph. The previous studies have also found that water in the Hasanpur block of this district is highly polluted due to industrial discharge in streams [5]. 


\begin{tabular}{|c|c|c|c|c|c|c|c|c|c|c|c|c|c|c|c|c|}
\hline SID & LOCATION & $\mathrm{pH}$ & $\mathrm{EC}$ & TDS & $\mathrm{CO} 3$ & $\mathrm{HCO} 3$ & H4SiO4 & P04 & $\mathrm{Cl}$ & SO4 & NO3 & $\mathrm{F}$ & $\mathrm{Na}$ & $\mathrm{K}$ & $\mathrm{Ca}$ & $\mathrm{Mg}$ \\
\hline 2 & ASIFABAD (handpump) & 8 & 740 & 256 & 0 & 280.6 & 149.9 & 9.48 & 195.9 & 112 & 18 & 0.6 & 9.8 & 4.9 & 72.8 & 14.4 \\
\hline $4 g$ & MISHRIPUR (canalwater) & 8.4 & 630 & 183 & 8.4 & 259.8 & 121.6 & 9.53 & 38.56 & 68 & 9 & 0.3 & 37.1 & 5.4 & 28.3 & 8.914 \\
\hline $6 g$ & GARHMUKTESHWAR(handpump) & 8.5 & 610 & 208 & 8.4 & 259.8 & 123.3 & 13.92 & 44.93 & 76 & 13 & 0.4 & 32.1 & 6 & 38 & 14.2 \\
\hline $6 \mathrm{r}$ & GARHMUKTESHWAR(riverwater) & 8.4 & 320 & 119 & 0 & 183 & 78.08 & 6 & 58.13 & 48 & 8 & 0.2 & 8.4 & 4.1 & 26.8 & 8.916 \\
\hline 7 & KABIRPUR (handpump) & 8.6 & 780 & 309 & 8.4 & 430.6 & 102.3 & 13.1 & 58.99 & 148 & 26 & 0.7 & 35 & 6.9 & 79 & 13.74 \\
\hline 10 & GAANGACHOLI(handpump) & 8.6 & 620 & 226 & 6 & 262.3 & 106.2 & 11.95 & 99.5 & 114 & 15 & 0.8 & 10.2 & 4 & 21.3 & 10.63 \\
\hline 13 & JALLOPUR(handpump) & 8.5 & 340 & 123 & 8.4 & 113.4 & 120.7 & 18.91 & 15.9 & 52 & 9 & 0.4 & 7.7 & 4.6 & 20 & 10.81 \\
\hline 15 & PAURARA(handpump) & 8.1 & 560 & 195 & 0 & 207.4 & 105.5 & 12.8 & 28.58 & 78 & 14 & 0.5 & 13.6 & 6.5 & 58 & 12.01 \\
\hline 16 & JEEPPUR(handpump) & 8.1 & 800 & 289 & 0 & 317.2 & 108.7 & 4.9 & 28.75 & 137 & 23 & 0.7 & 16.1 & 7 & 88.6 & 14.01 \\
\hline 17 & DEHRI(handpump)(redwater) & 8 & 1515 & 685 & 0 & 451.4 & 99.7 & 13.46 & 540.5 & 268 & 42 & 1.8 & 66.9 & 33.6 & 96.4 & 15.72 \\
\hline 18 & GAWAN(handpump) & 8 & 1025 & 390 & 0 & 451.4 & 117.6 & 12.89 & 230.7 & 186 & 28 & 1 & 43.9 & 8.7 & 90.3 & 15.42 \\
\hline 19 & TOWARDS REHRA (handpump) & 8.1 & 760 & 274 & 8.4 & 308.6 & 129 & 12.67 & 194.9 & 132 & 22 & 0.7 & 46.6 & 3 & 19.2 & 12.63 \\
\hline 21 & MATIPURA (handpump) & 8.4 & 660 & 232 & 8.4 & 259.8 & 121.8 & 13.07 & 86.19 & 113 & 18 & 0.6 & 41.2 & 20.9 & 83 & 10.94 \\
\hline 23 & SHAHPUR KALAN (handpump) & 8.6 & 420 & 163 & 24 & 158.6 & 136.5 & 16.44 & 58.99 & 64 & 10 & 0.2 & 12.6 & 3.7 & 23.5 & 11.37 \\
\hline 25 & UJHARI(handpump) & 8.5 & 480 & 187 & 8.4 & 174.4 & 144.9 & 13.56 & 142.9 & 70 & 12 & 0.4 & 23.7 & 5.5 & 55.8 & 11.22 \\
\hline 27 & NURPUR(handpump) & 7.8 & 1120 & 450 & 0 & 427 & 148 & 13.31 & 59.34 & 168 & 18 & 1 & 10.7 & 5.1 & 28.3 & 15.68 \\
\hline 29 & RAJOHA(handpump) & 7.7 & 1170 & 506 & 0 & 268.4 & 148.9 & 14.23 & 464.4 & 172 & 24 & 1.2 & 33.8 & 9 & 119.8 & 15.68 \\
\hline 30 & NEAR MANOTA(handpump) & 8.1 & 810 & 274 & 0 & 244 & 179.1 & 16.74 & 206.9 & 138 & 24 & 0.6 & 14.7 & 4.5 & 50.6 & 14.98 \\
\hline 32 & GARHMUKTESHWAR(handpump) & 8.8 & 770 & 329 & 60 & 183 & 136.2 & 18.11 & 245.3 & 162 & 26 & 0.8 & 25.2 & 5.8 & 72.8 & 14.97 \\
\hline 33 & KAKADHERA (handpump) & 8.8 & 830 & 292 & 8.4 & 259.8 & 110.3 & 15.6 & 57.21 & 138 & 22 & 0.5 & 11.6 & 9.1 & 86.9 & 13.16 \\
\hline $35 \mathrm{~g}$ & TIGRI (handpump) & 8.7 & 470 & 164 & 8.4 & 150 & 127.9 & 16.09 & 61.46 & 62 & 8 & 0.7 & 37.2 & 3.3 & 28.4 & 10.41 \\
\hline $35 r$ & TIGRI (ganga river water) & 8.4 & 240 & 100 & 8.4 & 89.06 & 76.24 & 10.51 & 38.39 & 38 & 4 & 0.05 & 6.2 & 3.5 & 20.2 & 10.46 \\
\hline 36 & CHAKANWALA (handpump) & 8.4 & 1050 & 393 & 6 & 347.7 & 110.5 & 30.47 & 378.5 & 171 & 26 & 0.8 & 50.5 & 9.1 & 84.4 & 15.52 \\
\hline 37 & MONDHA KHANDER (handpump) & 8.7 & 470 & 200 & 24 & 183 & 126.5 & 16.24 & 43.04 & 78 & 14 & 0.4 & 17.2 & 4.8 & 41.4 & 12.78 \\
\hline 38 & DHAUTI (handpump) & 8.6 & 330 & 132 & 8.4 & 125.6 & 134.2 & 15.45 & 39.37 & 56 & 12 & 0.3 & 11 & 2.8 & 17.9 & 10.26 \\
\hline 39 & DHANAURA (handpump) & 8.7 & 470 & 201 & 8.4 & 125.6 & 129.6 & 16.14 & 235.9 & 82 & 18 & 0.7 & 19.6 & 4.5 & 37.8 & 15.52 \\
\hline 40 & BACCHRAON (handpump) & 8.4 & 750 & 255 & 6 & 176.9 & 134.8 & 15.49 & 163.5 & 132 & 21 & 0.5 & 20.8 & 5.4 & 63.7 & 14.4 \\
\hline 41 & GAJRAULA(handpump) & 8.2 & 1010 & 393 & 6 & 115.9 & 158 & 15.9 & 398.4 & 180 & 32 & 0.8 & 25.6 & 5.3 & 113.3 & 13.91 \\
\hline 42 & RAJABPUR (handpump) & 8.5 & 560 & 198 & 8.4 & 113.4 & 138 & 15.66 & 153.3 & 78 & 13 & 0.4 & 19.2 & 5.5 & 42.2 & 14.4 \\
\hline 43 & ATRASI (handpump) & 8.5 & 570 & 183 & 8.4 & 113.4 & 125.7 & 15.75 & 151.6 & 72 & 12 & 0.5 & 17.9 & 4.2 & 52.4 & 13.91 \\
\hline 44 & DHANAURA ROAD(near Kankerhera)handpump & 8.5 & 720 & 219 & 8.4 & 125.6 & 141 & 15.19 & 255 & 112 & 13 & 0.6 & 33.8 & 4.5 & 58.8 & 14.39 \\
\hline 45 & TOWARDS NAOGAON (handpump) & 8.5 & 480 & 136 & 8.4 & 125.6 & 150.2 & 16.54 & 80.28 & 56 & 10 & 0.2 & 14.7 & 4.6 & 43.1 & 11.46 \\
\hline 46 & KANTH ROAD (handpump) & 8.5 & 470 & 146 & 8.4 & 113.4 & 148.3 & 15.18 & 80.17 & 56 & 6 & 0.4 & 15.6 & 4 & 35.6 & 13.02 \\
\hline \multirow[t]{5}{*}{47} & Kanth road (handpump)Kisan Inter college & 8.5 & 450 & 132 & 8.4 & 113.4 & 152 & 15.87 & 43.1 & 57 & 14 & 0.5 & 11.1 & 2.3 & 37.7 & 11.84 \\
\hline & $\operatorname{Max}$ & 8.8 & 1515 & 685 & 60 & 451.4 & 179.1 & 30.47 & 540.5 & 268 & 42 & 1.8 & 66.9 & 33.6 & 119.8 & 15.72 \\
\hline & Min & 7.7 & 240 & 100 & 0 & 89.06 & 76.24 & 4.9 & 15.9 & 38 & 4 & 0.05 & 6.2 & 2.3 & 17.9 & 8.914 \\
\hline & Average & 8.39 & 676.4 & 251.2 & 8.33 & 221.1 & 127.7 & 14.45 & 146.4 & 108 & 17.18 & 0.6 & 23.57 & 6.53 & 54.01 & 13 \\
\hline & SD & 0.28 & 279.3 & 125.4 & 10.74 & 107.2 & 22.01 & 4.17 & 133.8 & 52.82 & 8.26 & 0.33 & 14.6 & 5.76 & 28.9 & 2.06 \\
\hline
\end{tabular}

Table 1. Data of major parameters for the groundwater of the study area

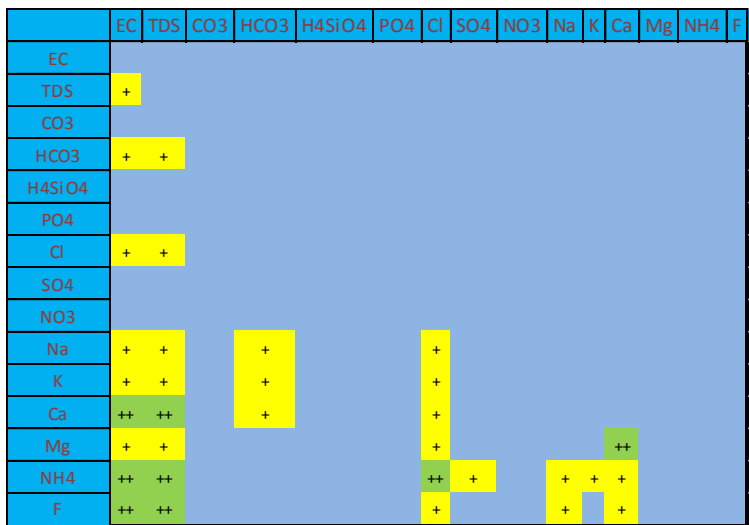

Table 2. Correlation matrix table of the calculated parameters + indicate $50-70 \%++$ indicate $>70 \%$ correlation.

Normalized charge balance index (NCBI) has been used to check the analytical precision of the data [11]. It is calculated as follows:

$$
\mathrm{NCBI}=\frac{\Sigma \text { anions }-\Sigma \text { cations }}{\Sigma \text { anions }-\Sigma \text { cations }}
$$

It should ideally vary from $-5 \%$ to $+5 \%$, which is very well obeyed in this case. (Fig. 3) 


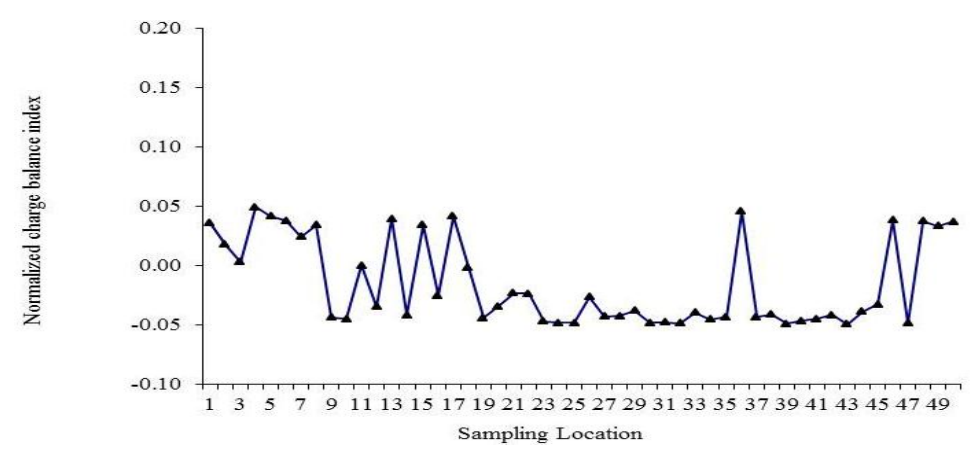

Figure 3.Normalized charge balance index plot

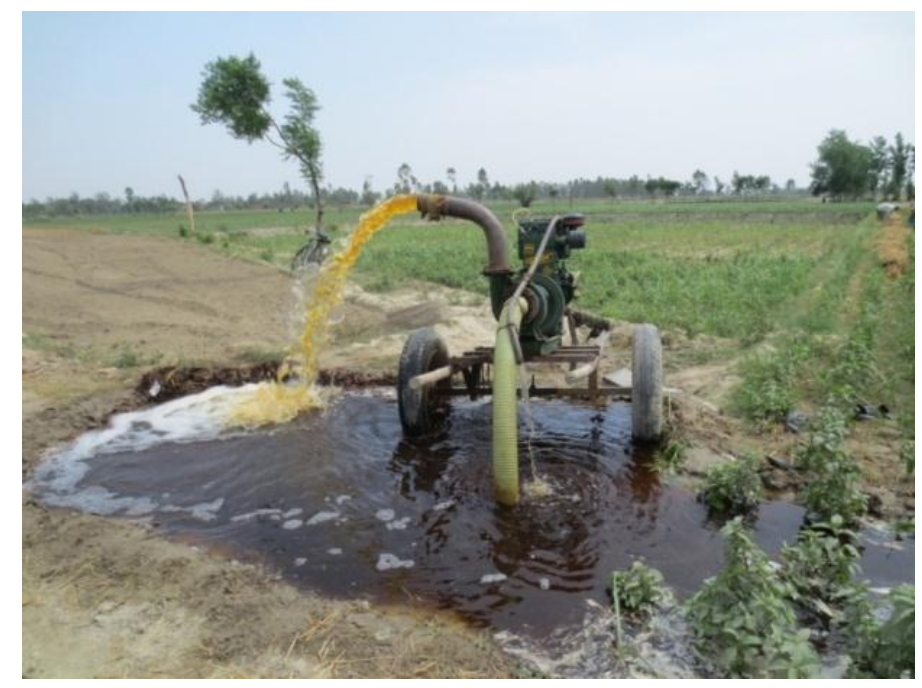

Plate1. Picture showing reddish yellow water from a borewell. This water is supposed to be polluted from discharge about 10 years before from a factory in Gajraula that released its waste material into an ephemeral stream (Tikta or Bagad) running parallel to Ganga(as told by a local villager). Since this is deep water, it is proving the fact that small streams have major role in recharging aquifers in this area.

$63 \%$ samples have $\mathrm{Ca}>\mathrm{Na}>\mathrm{Mg}>\mathrm{K}, 22.4 \%$ have $\mathrm{Ca}>\mathrm{Mg}>\mathrm{Na}>\mathrm{K}, 10 \%$ have $\mathrm{Na}>\mathrm{Ca}>\mathrm{Mg}>\mathrm{K}$, one sample at Asifabad from borewell has $\mathrm{Ca}>\mathrm{K}>\mathrm{Na}>\mathrm{Mg}$ and one at Dehri from borewell has $\mathrm{Ca}>\mathrm{Na}>\mathrm{K}>\mathrm{Mg}$. High $\mathrm{Na}$ content in $10 \%$ samples show that there is a significant anthropogenic contribution into the aquifer. $\mathrm{HCO}_{3}>\mathrm{Cl}>\mathrm{SO}_{4}$ and $\mathrm{HCO}_{3}>\mathrm{SO}_{4}>\mathrm{Cl}$ having $36.7 \%$ contribution each, $\mathrm{Cl}>\mathrm{SO}_{4}>\mathrm{HCO}_{3}, \mathrm{Cl}>\mathrm{HCO}_{3}>\mathrm{SO}_{4}$ and $\mathrm{SO}_{4}>\mathrm{HCO}_{3}>\mathrm{Cl}$ share the rest. High chloride and sulphate content in water may be attributed to the anthropogenic influence in the form of sewage or industrial discharge and application of fertilizers [12]. Bicarbonate source is more possibly from the $\mathrm{CO}_{2}$ dissolution and minerals in the alluvium like plagioclase feldspar [13].

\subsection{Hydrochemical Facies}

Hydrochemical diagrams help in determining evolution trends of groundwater system when linked with distribution maps [14]. In order to arrive at any concrete results, following methods have been explored to study the hydrochemical relationship in water.

\subsubsection{Chaddha diagram}

Chaddha diagram is a modification of the Hills Piper diagram to represent the water quality data in a simplest possible way [15]. On X-axis, it plots the difference in meq (milliequivalent) percentage between alkaline earths $(\mathrm{Ca}+\mathrm{Mg})$ and alkali metals $(\mathrm{Na}+\mathrm{K})$ and on $\mathrm{Y}$-axis, it plots the difference in meq percentage between weak acidic anions ( $\mathrm{HCO} 3+\mathrm{CO} 3)$ and strong acidic anions $(\mathrm{Cl}+\mathrm{SO} 4)$. Thus four fields are identified in this diagram. Samples falling in $\mathrm{Ca}-\mathrm{Mg}-\mathrm{HCO} 3$ field indicate temporary hardness while in $\mathrm{Ca}-\mathrm{Mg}-\mathrm{Cl}$ field show permanent hardness. It is found that samples which show permanent hardness are those collected next to river or dead channels which are contaminated from effluent discharge from various industries. Samples of the Amroha plain fall in Na-HCO3 field indicating saline conditions. This area is highly irrigated with canal water and groundwater and is not flooded.It leads to shallow groundwater tables (water-logging) and non-beneficial evaporation directly from that water table. Consequently, relatively mineralized water is left as a residue in the 
soil. From there it carries soil salinity and drain to surface water or percolates below the root zone. It may reach an aquifer and increase insalinity of its groundwater [16]. Groundwater samples near Gajraula and Hasanpur urban centres have temporary hardness. This may be due to underground formation rich in calcite and dolomite. Yellowish red coloured water samples (sample no.17, 19) fall in Na-Cl type suggesting foaming difficulty in domestic use. This may be due to industrial contamination.

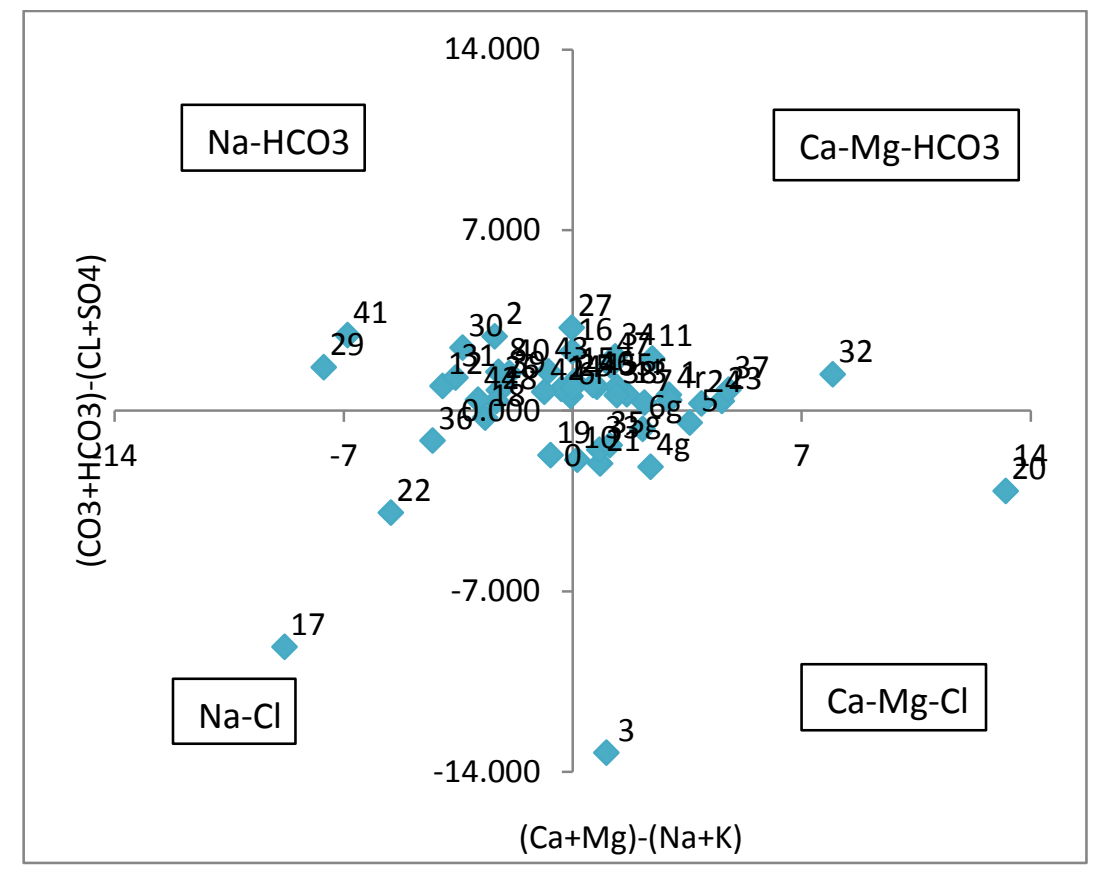

Figure 4.Chaddha plot describing the various water types.

\subsubsection{Piper and Durovplot}

Piper plot showed that major water type is $\mathrm{CaMgSO} 4$ and $\mathrm{CaMgHCO} 3$ along with mixed type. The dominance of Cacation and mixed representation of $\mathrm{Cl}, \mathrm{SO} 4$ and $\mathrm{HCO} 3$ is found. Durov diagram [17] showed that the majority of the samples fall below $400 \mathrm{mg} / \mathrm{l} \mathrm{TDS}$ and are basically of alkaline nature. Few samples are of $\mathrm{pH}<8$ and found in the southernmost part of the study area. Sample with highest TDS is yellowish red coloured sample from a borewell in Dehri village in southern part of the district.
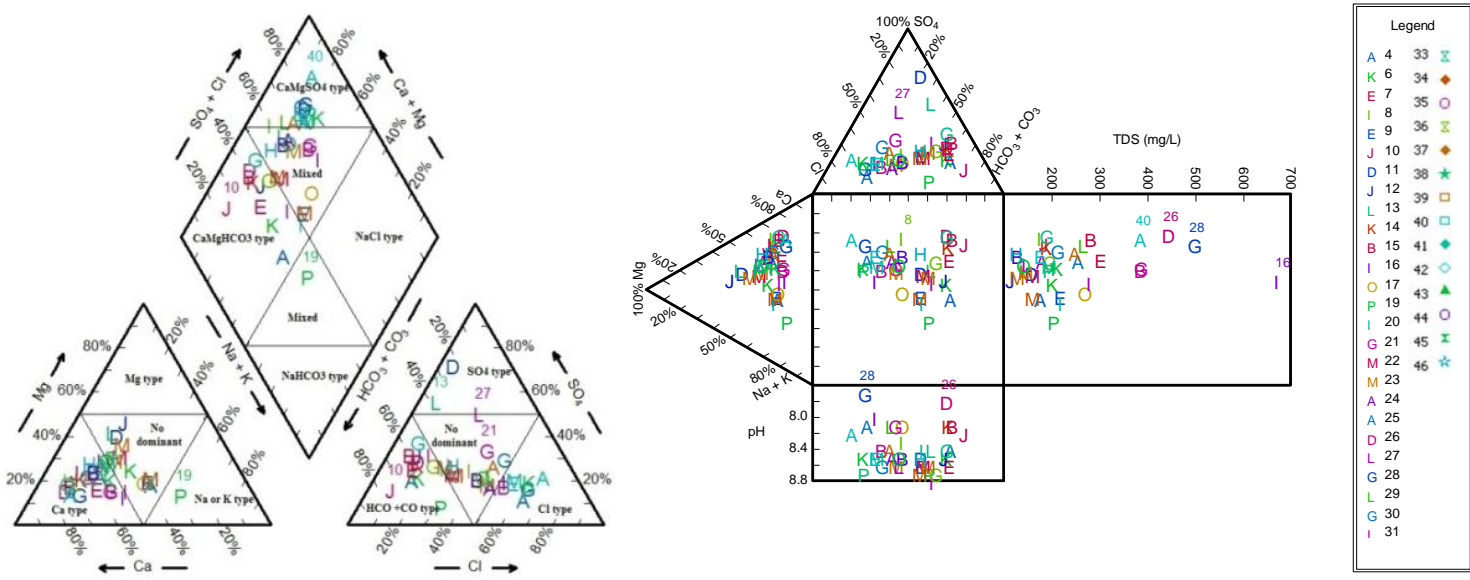

Figure 5.Piper plot (left) and Durov plot (right)

\subsection{Water Quality Index}

The hydrogeologists around the world have developed different method for assessing the groundwater quality through water quality index. Water quality index developed by Ramakrishnaiah et al. (2009) [18] has been used here to classify the water samples into excellent, good, poor, very poor for drinking purposes. Water 
quality index was calculated in two ways, firstly by taking into account $\mathrm{pH}, \mathrm{EC}$, TDS, TH, bicarbonate, carbonate, chloride, nitrate, sulphate, $\mathrm{Ca}, \mathrm{Mg}, \mathrm{Fe}, \mathrm{Mn}$ and $\mathrm{F}$ and secondly by taking into account $\mathrm{Cd}, \mathrm{Pb}, \mathrm{Cu}, \mathrm{Ni}$, $\mathrm{Hg}$, Se, As and CN along with the former. In the calculation of WQI, firstly each parameter is assigned a weight 'wi' according to its relative importance. For example, maximum weight 5 is assigned to nitrate and minimum weight 1 to $\mathrm{Mg}$ as per their relative importance. Secondly we calculate the relative weight 'Wi' as the ratio of weight assigned to parameter and the sum of weights assigned to all the parameters.

$$
\mathrm{Wi}=\mathrm{wi} / \sum_{\mathrm{i}=1}^{\mathrm{n}} \mathrm{wi}
$$

Where $\mathrm{Wi}$ is the relative weight, wi is the weight of each parameter and $\mathrm{n}$ is the number of parameters. In the third step,the quality rating scale 'qi' is calculated for each entry by the following formula:

$$
\mathrm{qi}=\left(\frac{\mathrm{Ci}}{\mathrm{Si}}\right) * 100
$$

Where $\mathrm{Ci}$ is the concentration of a parameter, $\mathrm{Si}$ is the $\mathrm{BIS}$ standard value according to latest guidelines (BIS IS 10500, 2009) In the fourth step, a sub-index SIi is calculated for each value by ,

$$
\text { SIi }=\text { Wi. qi }
$$

The final WQI is calculated by summing SI value for each parameter of a sample.

$$
\mathrm{WQI}=\sum \mathrm{SIi}
$$

\begin{tabular}{|c|c|c|c|}
\hline Parameters & Indian standard & Weight & Relative weight \\
\hline $\mathrm{pH}$ & $6.5-8.5$ & 4 & 0.098 \\
\hline $\mathrm{TH}$ & $300 \mathrm{ppm}$ & 2 & 0.049 \\
\hline $\mathrm{TDS}$ & $500 \mathrm{ppm}$ & 4 & 0.098 \\
\hline Bicarbonate ppm & $200 \mathrm{ppm}$ & 3 & 0.073 \\
\hline Chloride ppm & $250 \mathrm{ppm}$ & 3 & 0.073 \\
\hline Sulphate & $200 \mathrm{ppm}$ & 4 & 0.098 \\
\hline Nitrate & $45 \mathrm{ppm}$ & 5 & 0.122 \\
\hline $\mathrm{Ca}$ & $75 \mathrm{ppm}$ & 2 & 0.049 \\
\hline $\mathrm{Mg}$ & $30 \mathrm{ppm}$ & 1 & 0.024 \\
\hline $\mathrm{Fe}$ & $0.3 \mathrm{ppm}$ & 4 & 0.098 \\
\hline $\mathrm{Mn}$ & $0.1 \mathrm{ppm}$ & 4 & 0.098 \\
\hline Fluoride & $1.0 \mathrm{ppm}$ & 5 & 0.122 \\
\hline Total & & 41 & 1 \\
\hline \multicolumn{2}{|c}{} \\
\hline
\end{tabular}

Table 3.Relative weight of chemical parameter for WQI (A). For WQI (B), Cd, Pb, Cu, Ni, $\mathrm{Hg}$, $\mathrm{Se}$, As and CN were given each highest weight value of 5 .

\begin{tabular}{|c|c|c|c|c|c|}
\hline WQI value & $<50$ & $50-100$ & $100-200$ & $200-300$ & $>300$ \\
\hline $\begin{array}{c}\text { Water } \\
\text { quality }\end{array}$ & excellent & $\begin{array}{c}\text { good } \\
\text { water }\end{array}$ & $\begin{array}{c}\text { poor } \\
\text { water }\end{array}$ & $\begin{array}{c}\text { very poor } \\
\text { water }\end{array}$ & $\begin{array}{c}\text { Water unsuitable for } \\
\text { drinking }\end{array}$ \\
\hline
\end{tabular}

Table 4.WQI classification of water (Ramakrishnaiah et al. 2009)

Using GIS as a tool, the different water quality parameters were studied by spatial interpolation over ArcGIS 10 platform. This provided a great help to understand which areas as a whole are affected and which are not. In most of the cases, one can see N-W to S-E trend along mid-portion of the study area where a zone of high ionic concentration can be demarcated. In WQI spatial profile Figure 7(a) represent water quality variation only when 14 parameters are taken and the Figure 7(b) represent water quality variation when additional 8 parameters are also considered. WQI spatial profile has been categorized according to the interval defined manually whereas other profiles are categorized according to natural break method (Jenk's method). Jenks interval does not distort the normality of data while representing them spatially [19]. It is noted that the low quality area increases when additional parameters are also taken since they are hazardous for health. 

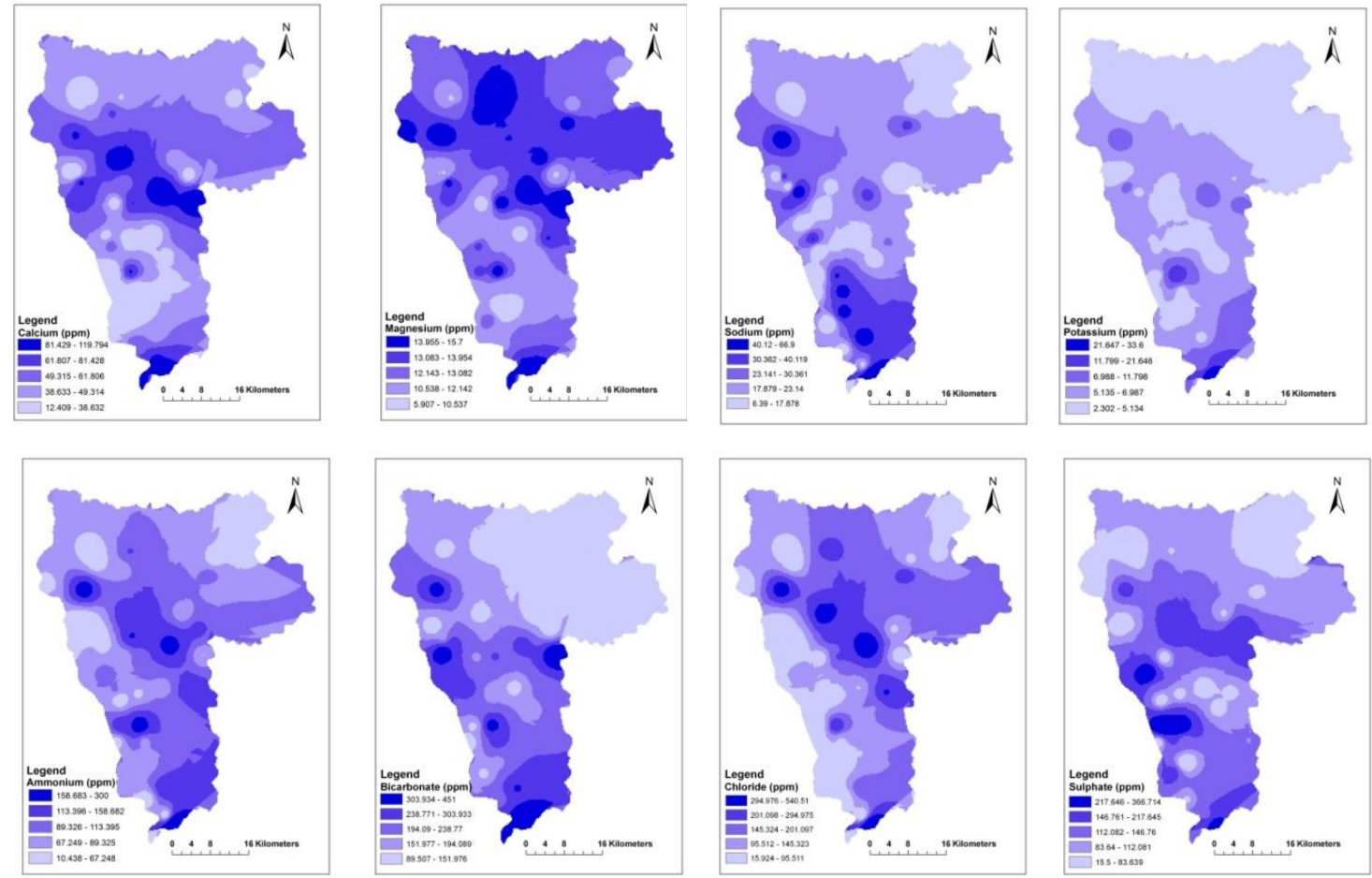

Figure 6.Spatial profile of major cations and anions using natural break (Jenks method).
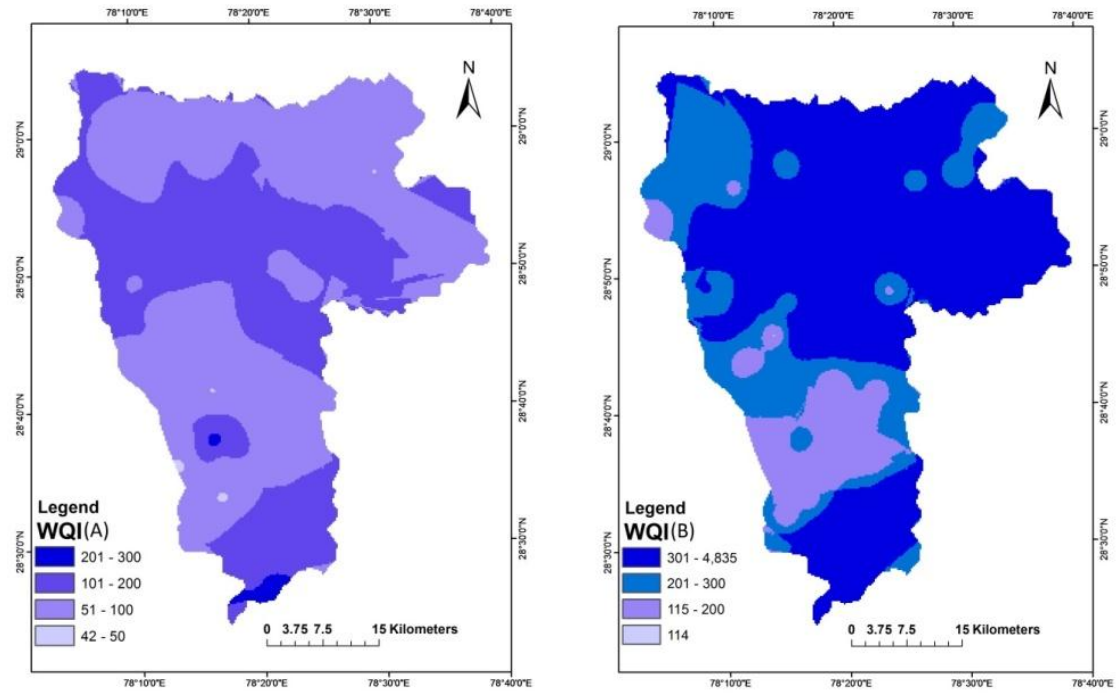

Figure 7.Spatial profile of water quality index, WQI(A) for only major ions and WQI(B) for hazardous elements included.

4.3 Mineralogy of the study area

The samples were prepared following method of Conolly, 2009 [20].The following minerals have been deciphered from XRD data manual interpretation,1. Quartz 2. Muscovite 3. Hornblende 4. Dolomite 5. Halite 6. Oligoclase 7. Orthoclase. So, these minerals control the groundwater quality in the study area. This helps in understanding the anthropogenic influence on ground water, since the anions or cations in excess of this minerals contribution can be deciphered as being from an unnatural source. 

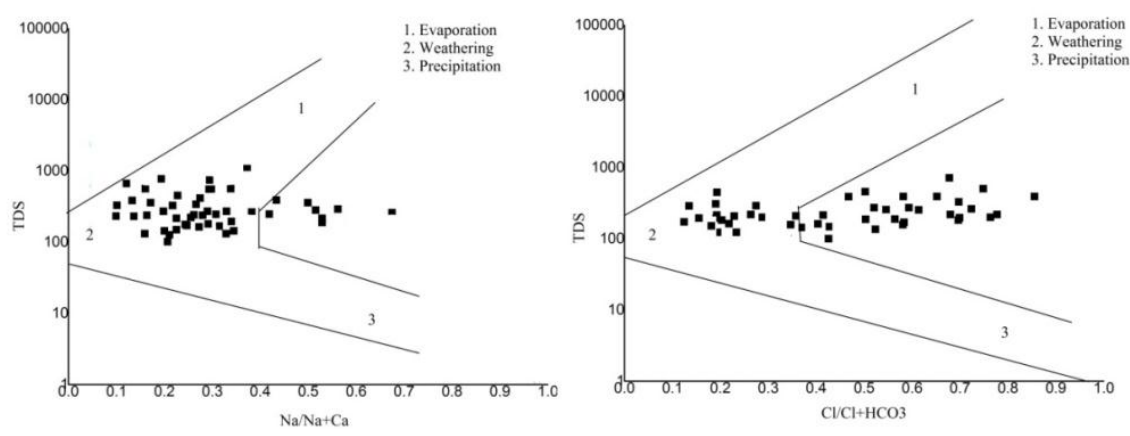

Figure 8. Mechanism controlling groundwater chemistry (Gibbs diagram showing weathering as the main source of dissolved constituents).Note: Lines drawn are just indicative not exact.

The Gibbs boomerang diagram shows that the chemical contents of groundwater have their source in weathering of minerals reported in XRD data [21].The anomalous increase in parameters like sulphate, phosphate and nitrate certainly has their source in anthropogenic source since no such minerals like gypsum are reported in XRD. The increased fluoride content most probably has their source in deep seated minerals of fluorapatite and fluorite, for which further research is required.

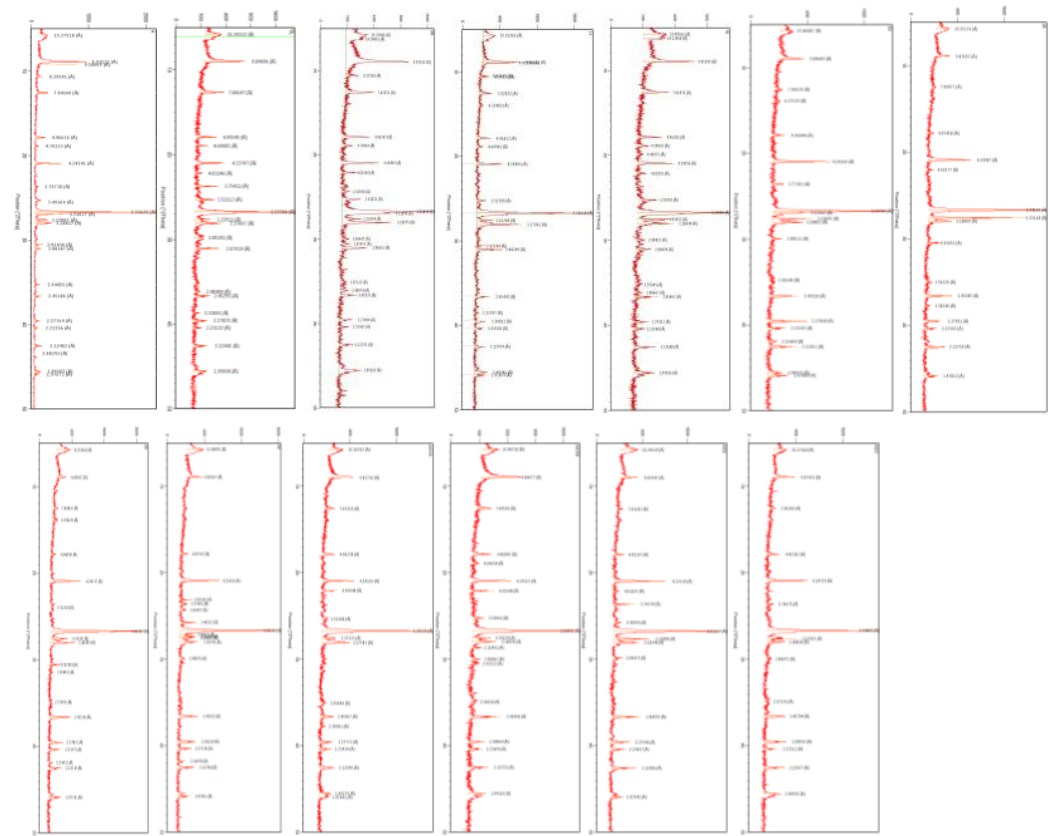

Figure 9. XRD graphs of soil sample (200mesh size) of the study area

4.4 Grain size variation in the study area

The grain size determination has been done by sieving method following the ASTM D 422 method which is the standard method for particle size analysis of soils. The result shows that samples near flood plain are muddy with good silt content but samples in interfluves older alluvium are sandy, with less silt. Further the results were analysed with the help of GRADISTAT v8.0 [22]. The results are shown below:

\begin{tabular}{|c|c|c|c|c|c|c|c|}
\hline ID & SAMPLE TYPE: & $\begin{array}{l}\text { TEXTURAL } \\
\text { GROUP: }\end{array}$ & SEDIMENT NAME: & MEAN: & SORTING: & SKEWNESS: & KURTOSIS: \\
\hline 28 & $\begin{array}{c}\text { Unimodal, } \\
\text { Moderately Sorted }\end{array}$ & Sand & $\begin{array}{l}\text { Moderately Sorted Fine } \\
\text { Sand }\end{array}$ & Fine Sand & $\begin{array}{l}\text { Moderately } \\
\text { Sorted }\end{array}$ & Symmetrical & Leptokurtic \\
\hline 9L & $\begin{array}{c}\text { Trimodal, Poorly } \\
\text { Sorted }\end{array}$ & $\begin{array}{l}\text { Muddy } \\
\text { Sand }\end{array}$ & $\begin{array}{l}\text { Very Coarse Silty } \\
\text { Medium Sand }\end{array}$ & $\begin{array}{l}\text { Very Fine } \\
\text { Sand }\end{array}$ & $\begin{array}{l}\text { Poorly } \\
\text { Sorted }\end{array}$ & Symmetrical & $\begin{array}{c}\text { Very } \\
\text { Platykurtic }\end{array}$ \\
\hline 9R & $\begin{array}{l}\text { Bimodal, Poorly } \\
\text { Sorted }\end{array}$ & $\begin{array}{l}\text { Sandy } \\
\text { Mud }\end{array}$ & $\begin{array}{c}\text { Very Fine Sandy Very } \\
\text { Coarse Silt }\end{array}$ & $\begin{array}{l}\text { Very Fine } \\
\text { Sand }\end{array}$ & $\begin{array}{l}\text { Poorly } \\
\text { Sorted }\end{array}$ & $\begin{array}{l}\text { Very Coarse } \\
\text { Skewed }\end{array}$ & Platykurtic \\
\hline 4 & $\begin{array}{l}\text { Trimodal, Poorly } \\
\text { Sorted }\end{array}$ & $\begin{array}{l}\text { Muddy } \\
\text { Sand }\end{array}$ & $\begin{array}{c}\text { Very Coarse Silty Very } \\
\text { Fine Sand }\end{array}$ & $\begin{array}{l}\text { Very Fine } \\
\text { Sand }\end{array}$ & $\begin{array}{l}\text { Poorly } \\
\text { Sorted }\end{array}$ & $\begin{array}{c}\text { Coarse } \\
\text { Skewed }\end{array}$ & Mesokurtic \\
\hline 24 & $\begin{array}{l}\text { Bimodal, Poorly } \\
\text { Sorted }\end{array}$ & $\begin{array}{l}\text { Muddy } \\
\text { Sand }\end{array}$ & $\begin{array}{c}\text { Very Coarse Silty } \\
\text { Medium Sand }\end{array}$ & Fine Sand & $\begin{array}{l}\text { Poorly } \\
\text { Sorted }\end{array}$ & Symmetrical & Mesokurtic \\
\hline
\end{tabular}




\begin{tabular}{|c|c|c|c|c|c|c|c|}
\hline 30 & $\begin{array}{c}\text { Trimodal, Poorly } \\
\text { Sorted }\end{array}$ & $\begin{array}{l}\text { Muddy } \\
\text { Sand }\end{array}$ & $\begin{array}{l}\text { Very Coarse Silty } \\
\text { Medium Sand }\end{array}$ & Fine Sand & $\begin{array}{l}\text { Poorly } \\
\text { Sorted }\end{array}$ & Fine Skewed & Mesokurtic \\
\hline 18 & $\begin{array}{l}\text { Trimodal, Poorly } \\
\text { Sorted }\end{array}$ & $\begin{array}{l}\text { Muddy } \\
\text { Sand }\end{array}$ & $\begin{array}{l}\text { Very Coarse Silty } \\
\text { Medium Sand }\end{array}$ & $\begin{array}{l}\text { Very Fine } \\
\text { Sand }\end{array}$ & $\begin{array}{l}\text { Poorly } \\
\text { Sorted }\end{array}$ & $\begin{array}{l}\text { Coarse } \\
\text { Skewed }\end{array}$ & Platykurtic \\
\hline 26 & $\begin{array}{l}\text { Bimodal, Moderately } \\
\text { Sorted }\end{array}$ & Sand & $\begin{array}{l}\text { Moderately Sorted Fine } \\
\text { Sand }\end{array}$ & Fine Sand & $\begin{array}{l}\text { Moderately } \\
\text { Sorted }\end{array}$ & Fine Skewed & Leptokurtic \\
\hline $\begin{array}{l}\mathbf{A S} \\
\mathbf{1 A}\end{array}$ & $\begin{array}{c}\text { Bimodal, Poorly } \\
\text { Sorted }\end{array}$ & $\begin{array}{l}\text { Muddy } \\
\text { Sand }\end{array}$ & $\begin{array}{c}\text { Very Coarse Silty } \\
\text { Medium Sand }\end{array}$ & Fine Sand & $\begin{array}{l}\text { Poorly } \\
\text { Sorted }\end{array}$ & $\begin{array}{l}\text { Coarse } \\
\text { Skewed }\end{array}$ & $\begin{array}{c}\text { Very } \\
\text { Platykurtic }\end{array}$ \\
\hline $\begin{array}{l}\mathrm{AS} \\
\mathbf{1 B}\end{array}$ & $\begin{array}{l}\text { Bimodal, Poorly } \\
\text { Sorted }\end{array}$ & $\begin{array}{l}\text { Muddy } \\
\text { Sand }\end{array}$ & $\begin{array}{c}\text { Very Coarse Silty Very } \\
\text { Fine Sand }\end{array}$ & $\begin{array}{l}\text { Very Fine } \\
\text { Sand }\end{array}$ & $\begin{array}{l}\text { Poorly } \\
\text { Sorted }\end{array}$ & Symmetrical & Mesokurtic \\
\hline $\begin{array}{c}\mathbf{A S} \\
2\end{array}$ & $\begin{array}{l}\text { Bimodal, Poorly } \\
\text { Sorted }\end{array}$ & $\begin{array}{l}\text { Muddy } \\
\text { Sand }\end{array}$ & $\begin{array}{c}\text { Very Coarse Silty } \\
\text { Medium Sand }\end{array}$ & Fine Sand & $\begin{array}{l}\text { Poorly } \\
\text { Sorted }\end{array}$ & Fine Skewed & Leptokurtic \\
\hline $\begin{array}{c}\mathbf{A S} \\
\mathbf{3}\end{array}$ & $\begin{array}{l}\text { Bimodal, Poorly } \\
\text { Sorted }\end{array}$ & $\begin{array}{l}\text { Muddy } \\
\text { Sand }\end{array}$ & $\begin{array}{l}\text { Very Coarse Silty } \\
\text { Medium Sand }\end{array}$ & Fine Sand & $\begin{array}{l}\text { Poorly } \\
\text { Sorted }\end{array}$ & Fine Skewed & Mesokurtic \\
\hline
\end{tabular}

Table 5. Grain size description of the sample in the study area. Sample ID location is shown in the Fig.10.

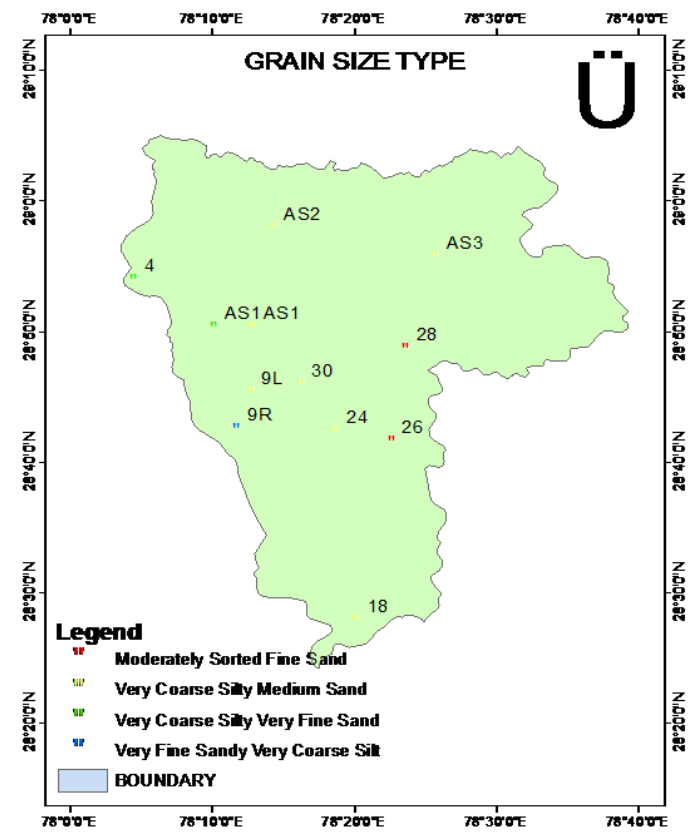

Figure 10.Grain size types and their location in the study area

\subsection{Land Cover Change in the Study area}

Land cover classes in the study area have been broadly classified as a). Cultivation b). Dense Vegetation c). Sand d). Settlement and e). Waterbody. This classification has been adopted considering the geomorphology of the area and classification adopted by NRSC (National Remote Sensing Centre, India). Landsat-7 TM image of March 1998 and Landsat -8 image of March 2013 downloaded from USGS Earth explorer have been used to classify using supervised method in ERDAS Imagine 9.3 software. Nearest neighbourhood classifier algorithm was used for this purpose. After classification, area of different classes was calculated with the histogram values. The result shows that there has been a marginal increase in cultivation and major sand patches have been brought under cultivation or used for settlement. This has been possible through irrigation from borewell which has witnessed a sharp increase in the last decades [23]. Infrastructure development in the form of electricity and subsidy given to farmers has led to this over exploitation of groundwater (Fig. 12). 

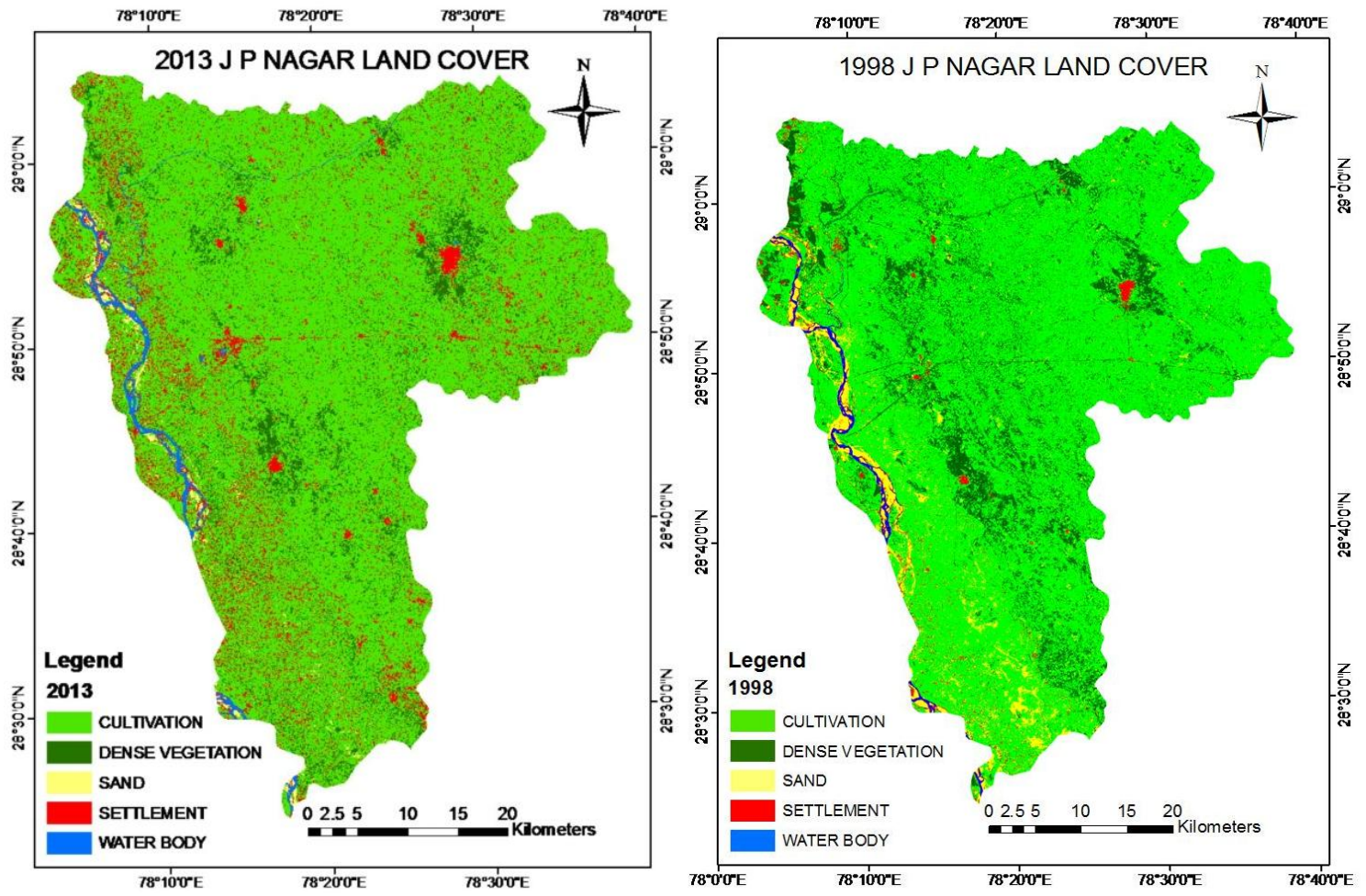

Figure 11. Supervised classification map of 2013 and 1998 USGS Landsat data.

$\begin{array}{llll}\text { Land Cover } & \mathbf{1 9 9 8} & \mathbf{2 0 1 3} & \text { Change } \\ \text { Cultivation } & 1752.75 & 1787.548 & \text { increase } \\ \text { Dense Vegetation } & 358.08 & 240.893 & \text { decrease } \\ \text { Sand } & 2487.59 & 17.613 & \text { decrease } \\ \text { Settlement } & 41.107 & 201.262 & \text { increase } \\ \text { Waterbody } & 16.032 & 29.409 & \text { increase }\end{array}$

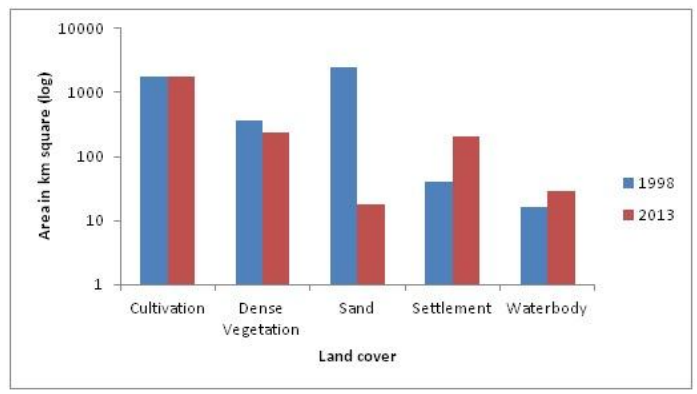

Figure 12. Table of area in $\mathrm{km}^{2}$ (left) and bar diagram (right) showing the change

\begin{tabular}{|c|c|c|c|c|c|c|c|c|c|c|c|c|c|}
\hline \multirow[b]{3}{*}{ District } & \multicolumn{4}{|c|}{ Annual Replenishable Ground Water Resource } & \multirow[t]{3}{*}{ Total } & \multirow{3}{*}{$\begin{array}{c}\text { Natural } \\
\text { Discharge } \\
\text { during non } \\
\text { Monsoon } \\
\text { period }\end{array}$} & \multirow[b]{3}{*}{$\begin{array}{c}\text { Net } \\
\text { ground } \\
\text { water } \\
\text { availabi } \\
\text { lity }\end{array}$} & \multicolumn{3}{|c|}{ Annual groundwater draft } & \multirow{3}{*}{$\begin{array}{c}\text { Projected } \\
\text { demand } \\
\text { for } \\
\text { domestic } \\
\text { and } \\
\text { industrial } \\
\text { water use } \\
2025\end{array}$} & \multirow[b]{3}{*}{\begin{tabular}{|c} 
Net \\
groundwater \\
availability \\
for future \\
irrigation use
\end{tabular}} & \multirow[b]{3}{*}{$\begin{array}{c}\text { Stage of } \\
\text { groundwater } \\
\text { development } \\
\%\end{array}$} \\
\hline & \multicolumn{2}{|c|}{ Monsoon season } & \multicolumn{2}{|c|}{ Non-Monsoon season } & & & & & & & & & \\
\hline & $\begin{array}{l}\text { Recharge } \\
\text { from rainfall }\end{array}$ & $\begin{array}{l}\text { Recharge } \\
\text { from other } \\
\text { sources }\end{array}$ & $\begin{array}{l}\text { Recharge } \\
\text { from rainfall }\end{array}$ & $\begin{array}{l}\text { Recharge } \\
\text { from other } \\
\text { sources }\end{array}$ & & & & Irrigation & $\begin{array}{c}\text { Domestic } \\
\text { and } \\
\text { industrial } \\
\text { water } \\
\text { supply }\end{array}$ & Total & & & \\
\hline P Nagal & 44438 & 5952 & 5596 & 8759 & 64745 & 4222 & 60523 & 61581 & 2878 & 64459 & 3032 & -4090 & 107 \\
\hline
\end{tabular}

Table 6. Ground water resource availability, utilization and stage of development, J P Nagar, U P, 2009.[23]

\section{Conclusion}

Overall, the alkaline nature of groundwater is revealed by $\mathrm{pH}$ 8.6. Correlation matrix has shown that $\mathrm{Ca}, \mathrm{Na}, \mathrm{K}$ and $\mathrm{HCO}_{3}$ are well correlated with dominance of $\mathrm{Ca}$. The yellowish red coloured sample indicates that aquifer is contaminated in the region. Relative percentage of cations and anions also indicates that $\mathrm{Ca}$ and $\mathrm{HCO}_{3}$ forms the background concentration and characterize the area. Bicarbonate dominance in overall whole area is visible through the box plot. MRD has also proved that water quality is $\mathrm{SO}_{4}$ and $\mathrm{Cl}$ type in highly polluted areas and $\mathrm{HCO}_{3}$ type in normal area. High EC in Amroha plain is well established by saline condition observed in Chaddha plot. Excess irrigation with canal water and groundwater leads to temporary shallow groundwater table that concentrates salts in dry season and percolates to increase EC. Piper and Durov also showed that TDS is mainly constituted by $\mathrm{Ca}, \mathrm{HCO}_{3}, \mathrm{Cl}$ and $\mathrm{SO}_{4}$. WQI or water quality index has found that a broad zone running across from NW-SE direction and southern most part is highly affected by water quality issues. Dissolution is found to increase in Ganga Khadar as found by lowering of saturation indices due to groundwater and river water interaction. Gibbs plot confirms that weathering from soil is the main source of minerals in the water. The 
change detection performed on Landsat data brings out the fact that rapid urbanization in Gangetic alluvial plain has great impact on groundwater quality.

\section{Acknowledgment}

I would like to acknowledge CSIR for providing financial assistance in terms of senior research fellowship. Further I am thankful to central instrumentation facility staff (B D Sharmaji and Rawat Sir) and AIRF-JNU staff (Dr. Manoj) for their cooperation in analysis work. At last, I acknowledge the contribution of my colleagues and lab attendant Sh. Daya Ram Yadavji for their selfless help.

\section{References}

[1] S.Das, Indo-Ganga-Brahmaputra basin overexploited- Myth or Reality? 2009

[2] R. Umar, M. Muqtada, A. Khan and A. Absar, Groundwater hydrochemistry of a sugarcane cultivation belt in parts of Muzaffarnagar district, Uttar Pradesh, India.Environ Geol, 49, 2006, 999-1008,doi 10.1007/s00254-005-0138-4

[3] W. Back, Hydrochemicalfacies and ground-water flow patterns in northern part of Atlantic Coastal Plain. Hydrology of aquifer systems. US Geological survey professional paper, 1964, 498-A.

[4] N Rajmohan and L. Elango, Identification and evolution of hydrogeochemical processes in the groundwater environment in an area of the Palar and Cheyyar River Basins, Southern India.Environmental Geology, 46,2004,47-61,doi 10.1007/s00254-004-1012-5.

[5] D. K. Sinha and R. Saxena, Statistical assessment of underground drinking water contamination and effect of monsoon at Hasanpur, J. P. Nagar (Uttar Pradesh, India).Journal of Environ. Science and Engg, 47(4),2006, 326-335.

[6] B. K. Bajpai, Base line survey in the minority concentrated districts of Uttar Pradesh (JyotibaPhuleNagar). Sposored by: Ministry of Minority Affairs, Government of India, New Delhi, Giri Institute of Development Studies, Sector-O, Aliganj Housing Scheme, Lucknow, India, 2006.

[7] B. K. Roy, Regional divisions of India- a cartographic analysis series 1, Uttar Pradesh, 22,1989, Samrat Press.

[8] E. Diatloff and Z. Rengel, Compilation of simple spectrophotometric techniques forthe determination of elements in nutrient solutions.Journal of PlantNutrition, 24(1),2006, 75-86, doi: 10.1081/pln-100000313.

[9] J. K. Bohlke, R. L. Smith and D. N. Miller,Ammonium transport and reaction in contaminated groundwater: Application of isotope tracers and isotope fractionation studies. Water Resources Research, 42,2006, W05411,doi:10.1029/2005WR004349.

[10] S. N. Davis and R. J. M DeWeist., Hydrogeology. Wiley, 1966. 463 pp

[11] Y. Huh, and J. M. Edmond, The fluvial geochemistry of the rivers of Eastern Siberia: III. Tributaries of the Lena and Anabar draining the basement terrain of the Siberian Craton and the Trans-Baikal Highlands.GeochimicaetCosmochimicaActa, 1999, 63(7/8), 967-987.

[12] F. A. Abdalla and T. Scheytt, Hydrochemistry of surface water and groundwater from a fractured carbonate aquifer in the Helwan area, Egypt.J. Earth Syst. Sci., 2012, 121: 109-124.

[13] P. Srivastava and B. Prakash,.Polygenetic Soils of the North-Central Part of the Gangetic Plains: A Micromorphological Approach. Catena,46 (4) 1, 2002, 243-259.

[14] N. J. Raju, Hydrogeochemical parameters for assessment of groundwater quality in the upper Gunjanaeru River basin, Cuddapah District, Andhra Pradesh, South India. Environ Geol, 52, 2007, 1067-1074. doi 10.1007/s00254-006-0546-0.

[15] D. K. Chadha, A proposed new diagram for geochemical classification of natural waters and interpretation of chemical data.Hydrogeol J,7, 1999,431-439.

[16] F. Weert, J. Gun and J. Reckman, Global overview of saline groundwater occurrence and genesis. International Groundwater Resource Assessment Centre. Report nr. , 2009,GP 2009-1.

[17] S. A. Durov, Natural waters and graphic representation of their composition. Dokl.Akad.Nauk,SSSR, 59, 1948, 87-90.

[18] C. R. Ramakrishnaiah, C. Sadashivaiah and G. Ranganna , Assessment of water quality index for the groundwater in TumkurTaluk, Karnataka State, India.E-Journal of Chemistry,6(2), 2009, 523-530.

[19] G. F. Jenks and F. C. Caspall, Error onchoroplethicmaps: Definition, Measurement, Reduction. Annals of the Association of American Geographers,61(2), 1971.

[20] J. R. Connolly, Sample Preparation and Systematic Diffractometer Errors, (for EPS400-001, Introduction to X-Ray Powder Diffraction, Spring 2009).

[21] R. J. Gibbs, Mechanisms controlling world water chemistry. Science, New Series, 170(3962), 1970, 1088-1090.

[22] S. J. Blott and K. Pye, Gradistat: a grain size distribution and statistics package for the analysis of unconsolidated sediments. Earth Surf. Process. Landforms 26, 1237-1248, 2001, DOI: 10.1002/esp.261.

[23] Report on Dynamic Ground Water Resources Of India (As On 31 March 2009).Central Ground Water Board Ministry of Water Resources, Government of India, Faridabad, 2011, 103. 